\title{
MENINGKATKAN KETERAMPILAN BERHITUNG PESERTA DIDIK PADA OPERASI HITUNG BILANGAN BULAT DENGAN PENGGUNAAN MEDIA KELERENG WARNA UNTUK KELAS II SEKOLAH DASAR
}

\author{
Ernawati Jais $^{\text {l) }}$, Fadly Satryo Guntara All Farisman ${ }^{2)}$ \\ Pendidikan Matematika FKIP Unidayan Baubau ${ }^{1), 2)}$ \\ jais_erna@yahoo.co.id ${ }^{1)}$, fadlysatryo.1996@gmail.com ${ }^{2)}$
}

\begin{abstract}
Abstrak
Tujuan penelitian ini adalah untuk mengetahui penggunaan media kelereng warna dapat meningkatkan keterampilan berhitung peserta didik pada operasi hitung bilangan bulat untuk kelas II Sekolah Dasar. Penelitian Tindakan Kelas (PTK) ini dilaksanakan di SD Negeri 2 Katobengke pada semester genap tahun pelajaran 2017/2018. Subjek dalam penelitian ini adalah peserta didik kelas II B, yang terdiri dari 23 peserta didik yaitu 11 siswa dan 12 siswi. Obyek penelitian yaitu media kelereng warna pada pembelajaran penjumlahan dan pengurangan bilangan bulat mata pelajaran Matematika. Prosedur/langkah-langkah Penelitian Tindakan Kelas ini terdiri dari siklus-siklus. Pelaksanaan Penelitian Tindakan Kelas ini setiap siklus meliputi: perencanaan, pelaksanaan tindakan, observasi, dan refleksi. Instrumen yang digunakan dalam penelitian ini adalah soal tes awal, soal tes akhir tiap siklus, dan pedoman wawancara. Soal yang dibuat terdiri dari 10 nomor berbentuk essay test. Hasil penelitian adalah bahwa penggunaan media kelereng warna dalam operasi hitung bilangan bulat dapat meningkatkan keterampilan berhitung peserta didik kelas II B SD Negeri 2 Katobengke.
\end{abstract}

Kata kunci: keterampilan berhitung, bilangan bulat, penggunaan media, kelereng berwarna

\begin{abstract}
Objective of this research was to find out the use of colored marbles media in increasing students' calculation ability on Integers Calculation Operation at grade II of elementary school. This classroom action research was conducted at SD Negeri 2 Katobengke in even semester of school year of 2017/2018. Subject in this research was students at class II B, which consisted of 23 students, those were 11 male students and 12 female students. Object of the research was colored marbles media on learning Adding and Subtraction of Integers from Mathematics subject. Procedures/steps of this classroom action research consisted of cycles. Implementation of this classroom action research for each cycle included: planning, acting, observing, and reflecting. Instruments used in this research was pretest question, posttest question, and interview guide. The questions made consisted of 10 items of essay test. Research outcome was the use of colored marbles media in Integers Calculation Operation could increase students' calculation ability at class II B of SD Negeri 2 Katobengke.
\end{abstract}

Keywords: calculation ability, Integers, media use, colored marbles

\section{PENDAHULUAN}

Pada anak usia SD yang sedang mengalami perkembangan dalam tingkat berpikir memerlukan stimulus untuk lebih memahami materi dalam mata pelajaran matematika agar lebih berpikir logis dan kreatif. Dengan mengajarkan matematika secara lebih kreatif diharapkan mampu mengatasi kesulitan-kesulitan belajar yang dialami oleh peserta didik. Oleh karena itu, pembelajaran matematika sangat membutuhkan kejelian dan ketelitian guru agar peserta didik mampu menguasai pelajaran matematika.

Materi pelajaran matematika yang harus dipelajari salah satunya adalah bilangan bulat. Bilangan bulat merupakan salah satu pokok bahasan yang harus dikuasai oleh peserta didik. Bilangan bulat adalah bilangan bukan pecahan yang terdiri bilangan bulat negatif, nol, dan bulat positif (Anonim, 2010, p.1). Bilangan bulat dinyatakan dengan $\mathrm{B}=\{\ldots,-3,-2,-1,0,1,2,3$, ...\}. Operasi hitung pada bilangan bulat yang diterapkan di SD sangatlah penting, hal ini dimaksudkan agar peserta didik lebih memahami dan menguasai secara penuh bilangan bulat beserta operasi hitung didalamnya. Oleh karena itu, peneliti mengkaji dan meneliti lebih dalam mengenai kemampuan serta keterampilan menghitung peserta didik di kelas II SD Negeri 2 Katobengke pada operasi bilangan bulat khususnya penjumlahan dan pengurangan perlu dilakukan. Oleh karena, operasi bilangan bulat di 
kelas II sebagai dasar dalam kemampuan menghitung dan apabila kemampuan menghitung pada operasi bilangan bulat di kelas II tidak segera dilakukan, maka besar kemungkinan akan menganggu pembelajaran di tingkat selanjutnya.

Berdasarkan hasil ulangan mata pelajaran matematika, data yang diperoleh menunjukkan bahwa peserta didik kelas II SD Negeri 2 Katobengke masih dibawah KKM yaitu 60. Hal ini dilihat dengan hanya ada $35 \%$ siswa yang mendapat nilai 60 atau lebih, dan $65 \%$ siswa mendapat nilai di bawah 60 .

Salah satu penyebab rendahnya keterampilan menghitung peserta didik dalam pembelajaran matematika yaitu karena pembelajaran yang dilaksanakan guru masih bersifat konvensional. Pembelajaran yang hanya bersifat satu arah, dimana guru bersikap lebih aktif dengan mencari dan menjelaskan materi/informasi sedangkan siswa hanya bersikap pasif mendengarkan materi/informasi yang diberikan oleh guru. Pembelajaran secara konvensional membuat siswa kurang memahami konsep dalam pelajaran matematika. Jadi siswa tidak bisa memahami pelajaran yang disampaikan oleh guru sehingga keterampilan berhitungnya tidak sesuai dengan yang diharapkan. Oleh karena itu,perlu dirancang suatu model pembelajaran operasi bilangan bulat dengan menggunakan alat bantu mengajar (media) yang mudah didapat atau dibuat oleh guru, dan bermanfaat bagi peningkatan kualitas pembelajaran matematika.

Salah satu media yang dapat digunakan untuk menjelaskan pokok bahasan bilangan bulat adalah media kelereng warna. Media kelereng warna khususnya dapat digunakan untuk menjelaskan materi operasi hitung penjumlahan dan pengurangan bilangan bulat. Media kelereng warna berbentuk lingkaran. Media kelereng warna terdiri atas dua warna, satu warna untuk menandakan atau mewakili bilangan bulat positif, warna yang satunya lagi untuk menandakan atau mewakili bilangan bulat negatif sedangkan kelereng berwarna bilangan bulat positif dan kelereng berwarna bilangan bulat negatif menunjukkan bilangan nol apabila saling berdempetan atau berpasangan.

Berdasarkan latar belakang masalah diatas, maka peneliti merumuskan masalah sebagai berikut: Apakah penggunaan media kelereng warna dapat meningkatkan keterampilan berhitung peserta didik pada operasi hitung bilangan bulat untuk kelas II Sekolah Dasar?

\section{METODE PENELITIAN}

\section{Setting Penelitian}

Penelitian Tindakan Kelas (PTK) ini dilaksanakan di SD Negeri 2 Katobengke pada semester genap tahun pelajaran 2017/2018.

\section{Subyek dan Obyek Penelitian}

Subjek dalam penelitian ini adalah peserta didik kelas II B SD Negeri 2 Katobengke tahun pelajaran 2017/2018 semester genap, yang terdiri dari 23 peserta didik yaitu 11 siswa dan 12 siswi. Obyek penelitian yaitu media kelereng warna pada pembelajaran penjumlahan dan pengurangan bilangan bulat mata pelajaran Matematika.

\section{Prosedur Penelitian}

Prosedur/langkah-langkah Penelitian Tindakan Kelas ini terdiri dari siklus-siklus. Pelaksanaan Penelitian Tindakan Kelas ini setiap siklus meliputi: perencanaan, pelaksanaan tindakan, observasi, dan refleksi.

Siklus I

Tahap perencanaan tindakan, meliputi langkah-langkah sebagai berikut: 1) Membuat rencana pelaksanaan pembelajaran (RPP) mengenai materi penjumlahan dan pengurangan bilangan bulat. 2) Merancang pembuatan media pembelajaran berupa media kelereng warna yang menunjang pembelajaran. 3) Menyiapkan soal evaluasi yang sesuai dengan materi pembelajaran; 4) Membuat instrumen observasi untuk pelaksanaan pembelajaran.

Tahap pelaksanaan tindakan, meliputi langkah-langkah sebagai berikut: 1) Pendahuluan, pada bagian ini guru mengkondisikan peserta didik untuk mengikuti pembelajaran secara kondusif dan memberikan apersepsi dengan memberikan soal-soal sesuai materi. 2) Kegiatan inti, pada bagian ini peserta didik melakukan operasi hitung penjumlahan dan pengurangan bilangan bulat dengan menggunakan media kelereng warna. 3) Penutup, pada akhir pembelajaran guru dan peserta didik menyimpulkan materi yang telah dipelajari.

Tahap pengamatan/pengumpulan data (observasi). Observasi dilaksanakan pada saat pembelajaran berlangsung. Observasi dilaksanakan terhadap aktivitas peserta didik pada saat melaksanakan pembelajaran dengan menggunakan pedoman lembar observasi siswa.

Tahap refleksi; Refleksi dilakukan untuk mengevaluasi kegiatan perencanaan, pelaksanaan 
dan observasi serta menganalisa hasil belajar dan hasil observasi.

Jika pada siklus ini peserta didik sudah mencapai indikator kinerja yang diinginkan, yaitu $75 \%$ peserta didik telah mendapat nilai lebih dari 65 , berarti penelitian telah berhasil oleh karena itu penelitian tidak perlu dilanjutkan ke siklus berikutnya. Tetapi jika belum mencapai indikator yang diinginkan, yaitu peserta didik dengan nilai di atas 65 belum mencapai $75 \%$, maka penelitian dilanjutkan ke siklus berikutnya.

\section{Instrumen dan Teknik Pengumpulan Data}

Instrumen yang digunakan dalam penelitian ini adalah soal tes awal, soal tes akhir tiap siklus, dan pedoman wawancara. Soal yang dibuat terdiri dari 10 nomor berbentuk essay test.

Teknik pengumpulan data yang digunakan untuk mengumpulkan data dari penelitian ini adalah sebagai berikut: 1) Melakukan observasi untuk mengetahui perilaku peserta didik dalam belajar matematika, interaksi guru dengan peserta didik, peserta didik dengan peserta didik selama proses pembelajara berlangsung. 2) Melakukan wawancara, untuk mengetahui tanggapan peserta didik dan guru terhadap proses pembelajaran dengan menggunakan media kelereng warna. 3) Melakukan tes yang akan dilaksanakan pada setiap siklus untuk mengetahui keterampilan peserta didik dalam menghitung pada materi operasi hitung bilangan bulat.

\section{Teknik Analisis Data}

Data dalam penelitian ini berupa hasil tes tentang operasi hitung bilangan bulat yang diberikan kepada peserta didik setiap akhir siklus dan hasil observasi dalam proses pembelajaran menggunakan media kelereng warna. Data yang diperoleh tersebut kemudian dianalisis untuk mengetahui hasil tindakan pada setiap siklus. Analisi data yang digunakan adalah sebagai berikut:

\section{Analisis Kuantitatif}

Dalam analisis kuantitatif, data dianalisis dengan menentukan mean/ rataan untuk setiap siklus. Adapun untuk menghitung rata-rata nilai peserta didik menurut Suharsimi Arikunto (2010, p.284-285):

$$
\bar{X}=\frac{\sum x}{n}
$$

Keterangan:

$\bar{X}=$ nilai rata-rata yang dicari

$\sum \mathrm{x}=$ jumlah nilai

$\mathrm{n} \quad=$ jumlah siswa
Untuk menghitung persentase ketuntasan belajar peserta didik, maka digunakan rumus (Daryanto, 2011, p.192):

Persentase $=\frac{\sum \text { siswa yang tuntas belajar }}{\sum \text { seluruh siswa }} \times 100 \%$

Analisis data observasi

Hasil observasi aktivitas peserta didik selama proses pembelajaran operasi hitung bilangan bulat dengan menggunakan media kelereng warna menghasilkan data kualitatif. Untuk menganalisis data kualitatif menggunakan model Milles dan Huberman dalam Ririn (2014, p.47) dengan model alur. Teknik ini terdiri dari tiga alur kegiatan yang berlangsung secara bersamaan yaitu reduksi data, penyajian data, penarikan kesimpulan atau verifikasi. Reduksi data adalah kegiatan pemilihan data, penyederhanaan data serta transformasi data kasar dari catatan pengamatan. Hasil reduksi berupa uraian singkat yang telah digolongkan dalam suatu kegiatan tertentu. Penyajian data berupa sekumpulan informasi dalam bentuk teks naratif yang disusun, diatur, diringkas dalam bentuk kategori-kategori sehingga mudah dipahami makna yang terkandung di dalamnya. Analisis data tersebut berguna untuk rencana perbaikan pembelajaran pada siklus berikutnya. Penarikan kesimpulan merupakan temuan baru yang sebelumnya belum pernah ada. Temuan berupa deskripsi atau gambaran suatu objek yang sebelumnya masih belum jelas sehingga setelah diteliti menjadi jelas.

Analisis ini dilakukan pada saat tahapan refleksi. Hasil analisis ini digunakan untuk melakukan perencanaan lanjut dalam siklus selanjutnya, sebagai bahan refleksi dalam memperbaiki rancangan pembelajaran. Kriteria Tingkat keberhasilan Belajar peserta didik dalam $\%$, dapat dilihat pada table berikut:

Tabel 1. Kriteria Keberhasilan Proses Pembelajaran Siswa dan Guru

\begin{tabular}{ccc}
\hline No. & $\begin{array}{c}\text { Tingkat } \\
\text { Keberhasilan }\end{array}$ & $\begin{array}{c}\text { Predikat } \\
\text { Keberhasilan }\end{array}$ \\
\hline 1 & $86-100 \%$ & Sangat Tinggi \\
2 & $71-85 \%$ & Tinggi \\
3 & $56-70 \%$ & Sedang \\
4 & $41-55 \%$ & Rendah \\
5 & $<40 \%$ & Sangat Rendah \\
& Rentang 15\% & \\
\hline
\end{tabular}

Sumber: Agip dkk, (2009, p.41) 


\section{HASIL PENELITIAN DAN PEMBAHASAN}

\section{Deskripsi Setting Penelitian}

\section{Deskripsi Kondisi Awal}

Pra tindakan dilaksanakan pada hari Sabtu tanggal 21 April 2018. Tahap pra tindakan dilaksanakan untuk memperoleh data awal mengenai keterampilan berhitung peserta didik pada operasi hitung bilangan bulat sebelum dilakukan tindakan. Data yang diperoleh pada tahap pra tindakan ini melalui pengenalan bilangan bulat dan pre test.

Tabel 2. Frekuensi Nilai Sebelum Tindakan

\begin{tabular}{cccc}
\hline No. & Nilai & Frekuensi & Presentase \\
\hline 1 & 70 & 3 & $13,04 \%$ \\
2 & 60 & 5 & $21,74 \%$ \\
3 & 40 & 4 & $17,4 \%$ \\
4 & 30 & 2 & $8,7 \%$ \\
5 & 20 & 6 & $26,08 \%$ \\
6 & 10 & 3 & $13,04 \%$ \\
\hline \multicolumn{2}{c}{ Jumlah } & 23 & $100 \%$ \\
\hline
\end{tabular}

Bertolak dari data tersebut, keterampilan berhitung peserta didik dalam materi operasi hitung penjumlahan dan pengurangan bilangan bulat masih rendah, maka dilakukan tindakan lanjutan untuk meningkatkan keterampilan berhitung peserta didik pada materi operasi hitung penjumlahan dan pengurangan bilangan bulat dengan menggunakan media kelereng warna.

Tabel 3. Tingkat Keberhasilan Peserta Didik Pada Pra Tindakan

\begin{tabular}{|c|c|c|c|}
\hline $\begin{array}{c}\text { Tingkat } \\
\text { Keberhasilan }\end{array}$ & $\begin{array}{c}\text { Predikat } \\
\text { Keberhasilan }\end{array}$ & $\begin{array}{c}\text { Banyak } \\
\text { Peserta } \\
\text { Didik }\end{array}$ & $\begin{array}{c}\text { Persentase } \\
\text { Jumlah } \\
\text { Peserta } \\
\text { Didik }\end{array}$ \\
\hline $86 \%-100 \%$ & Sangat Tinggi & 0 & $0 \%$ \\
\hline $71 \%-85 \%$ & Tinggi & 0 & $0 \%$ \\
\hline $56 \%-70 \%$ & Sedang & 8 & $35 \%$ \\
\hline $41 \%-55 \%$ & Rendah & 0 & $0 \%$ \\
\hline$\leq 40$ & Sangat Rendah & 15 & $65 \%$ \\
\hline \multicolumn{2}{|c|}{ Jumlah } & 23 & $100 \%$ \\
\hline
\end{tabular}

Berdasarkan pada tabel di atas maka dapat diketahui bahwa nilai pretes peserta didik dari 23 peserta didik pada mata pelajaran matematika, persentase ketuntasan belajar siswa adalah 8 peserta didik $(35 \%)$. Sedangkan peserta didik yang belum tuntas ada 15 peserta didik $(65 \%)$, dalam hal ini belum mencapai kriteria ketuntasan minimal yaitu $75 \%$.
Deskripsi Pelaksanaan Penelitian

Tindakan siklus I dilaksanakan mulai tanggal 7 Mei 2018 sampai 11 Mei 2018. Tindakan siklus 1 dilaksanakan dalam dua kali pertemuan, tiap pertemuan $3 \times 35$ menit. Adapun tahapan yang dilakukan sebagai berikut:

\section{Perencanaan Tindakan}

Peneliti menyusun rencana tindakan yang akan dilaksanakan untuk meningkatkan keterampilan berhitung peserta didik pada operasi hitung bilangan bulat dengan menggunakan media kelereng warna. Rencana tindakan yang akan dilaksanakan adalah sebagai berikut. 1) Memilih kompetensi dasar mengenai operasi hitung bilangan bulat dan membuat indikator serta tujuan pembelajaran yang dicapai oleh guru dalam pembelajaran. Alasan memilih kompetensi dasar atau indikator tersebut adalah: a) Kompetensi dasar tentang operasi hitung bilangan bulat harus benar- benar dikuasai oleh peserta didik, karena hal tersebut mempermudah penguasaan peserta didik terhadap materi secara penuh atau tuntas belajar serta kemungkinan besar tidak akan mengganggu pembelajaran di tingkat selanjutnya, khususnya di kelas selanjutnya. b) Kompetensi dasar tentang operasi hitung bilangan bulat nantinya dapat dipergunakan dalam kehidupan sehari-hari. 2) Menyusun Rencana Pelaksanaan Pembelajaran berdasarkan indikator serta tujuan pembelajaran. RPP disusun 2 kali pertemuan setiap siklus dengan alokasi waktu masing-masing 3 x 35 menit. 3) Menyiapkan media kelereng warna untuk digunakan dalam pembelajaran. 4) Menyususn lembar observasi yang di dalamnya berisi tentang kegiatan guru dan peserta didik dalam proses pembelajaran. 5) Menyiapkan soal evaluasi yang sesuai dengan materi pembelajaran.

\section{Pelaksanaan Tindakan}

Pada tahapan ini guru menerapkan pembelajaran sesuai dengan RPP yang telah disusun dengan menggunakan media kelereng warna. Pembelajaran pada siklus I dilaksanakan dalam dua kali pertemuan.

\section{Pertemuan ke-1}

Pada pertemuan ke 1, tahap pendahuluan materi yang diajarkan berupa penjumlahan bilangan bulat dengan indikator mampu menjumlahkan bilangan bulat positif dengan positif, mampu menjumlahkan bilangan bulat positif dengan negatif, mampu menjumlahkan 
bilangan bulat negatif dengan positif, mampu menjumlahkan bilangan negatif dengan negatif. Pembelajaran diawali dengan memberi salam, mengkondisikan peserta didik, kemudian guru memberikan apersepsi dan soal-soal serta tanya jawab dengan peserta didik mengenai penjumlahan bilangan bulat.

Kegiatan inti guru menjelaskan tentang konsep penjumlahan bilangan bulat dengan menggunakan media kelereng warna. Kemudian peserta didik mendemonstrasikan pengerjaan operasi hitung penjumlahan dengan menggunakan media kelereng warna. Kegiatan ini diulang beberapa kali serta tanya jawab dengan peserta didik seputar materi. Kegiatan selanjutnya untuk meningkatkan pemahaman peserta didik, guru mambagi peserta didik dalam 4 kelompok. Kemudian guru mulai memberikan media kelereng warna dan lembar soal untuk dikerjakan secara kelompok. Guru membimbing peserta didik secara bergiliran dan mengamati aktivitas peserta didik dalam pembelajaran. Setelah selesai lembar soal dikumpulkan, maka dilanjutkan dengan membahas bersama lembar kerja tersebut.

Pada akhir pertemuan pertama siklus I, guru belum melaksanakan evaluasi. Guru hanya memberikan tugas rumah kepada peserta didik untuk mempelajari materi yang sudah diajarkan dan untuk mempelajari operasi hitung pengurangan pada bilangan bulat serta banyak berlatih soal-soal agar pandai. Selain itu guru juga memberikan motivasi kepada peserta didik untuk terus mempelajari operasi hitung bilangan bulat. Guru menutup pembelajaran dengan salam penutup.

\section{Pertemuan ke-2}

Pada pertemuan ke 2, tahap pendahuluan materi yang diajarkan adalah pengurangan bilangan bulat dengan indikator mampu mengurangkan bilangan bulat positif dengan positif, mampu mengurangkan bilangan bulat negatif dengan negatif dan untuk mengurangkan bilangan bulat positif dengan negatif, bilangan bulat negatif dan positif peneliti belum menerapkannya untuk diajarkan dikelas II SD. Pembelajaran diawali dengan memberi salam, mengkondisikan peserta didik, kemudian guru memberikan apersepsi dan soal-soal serta tanya jawab dengan peserta didik mengenai penjumlahan bilangan bulat.

Kegiatan inti guru menjelaskan tentang konsep pengurangan bilangan bulat dengan menggunakan media kelereng warna. Kemudian peserta didik mendemonstrasikan pengerjaan operasi hitung pengurangan dengan menggunakan media kelereng warna. Kegiatan ini diulang beberapa kali serta tanya jawab dengan peserta didik seputar materi. Kegiatan selanjutnya untuk meningkatkan pemahaman peserta didik, guru mambagi peserta didik dalam 4 kelompok. Kemudian guru mulai memberikan media kelereng warna dan lembar soal untuk dikerjakan secara kelompok. Guru membimbing peserta didik secara bergiliran dan mengamati aktivitas peserta didik dalam pembelajaran. Setelah selesai lembar soal dikumpulkan, maka dilanjutkan dengan membahas bersama lembar kerja tersebut.

Pada akhir pertemuan kedua siklus I, guru belum melaksanakan evaluasi karena dibatasi oleh waktu. Guru hanya memberikan tugas rumah kepada peserta didik untuk mempelajari materi yang sudah diajarkan dan untuk mempelajari operasi hitung penjumlahan dan pengurangan pada bilangan bulat serta banyak berlatih soal-soal agar pandai. Selain itu guru juga memberikan motivasi kepada peserta didik untuk terus mempelajari operasi hitung bilangan bulat. Guru menutup pembelajaran dengan salam penutup. Evaluasi siklus I akan dilaksanakan pada hari jumat tanggal 11 Mei 2018 untuk melihat tingkat pencapaian keterampilan berhitung peserta didik. Pengukuran keterampilan berhitung peserta didik dilakukan dengan memberikan soal-soal kepada peserta didik (soal terdapat pada lampiran). Peserta didik mengerjakan soal evaluasi secara individu. Saat peserta didik sedang mengerjakan soal, guru berkeliling sambil memeriksa pekerjaan peserta didik.

\section{Observasi}

Observasi dilaksanakan untuk memperoleh data mengenai proses pembelajaran yang telah dilaksanakan. Berdasarkan observasi terhadap peserta didik selama kegiatan pembelajaran pada pertemuan ke-1 keaktifan peserta didik dalam menerima pelajaran cukup aktif. Adanya minat yang cukup baik tersebut, menjadikan peserta didik memiliki kepercayaan diri yang cukup baik sehingga peserta didik memiliki dorongan untuk mengerjakan soal dengan baik. Peserta didik pula sangat senang menggunakan media kelereng warna dalam berhitung bilangan bulat. Pada pertemuan ke-2 observasi terhadap aktivitas peserta didik, peserta didik cukup aktif dalam pembelajaran. Minat cukup baik mendorong peserta didik untuk mengerjakan soal dengan 
baik. Peserta didik pula sangat senang menggunakan media kelereng warna dalam berhitung bilangan bulat. Data hasil observasi pertemuan ke-1 dan pertemuan ke-2 pada siklus I.

Berdasarkan observasi terhadap guru (peneliti), guru (peneliti) telah melaksnakan pembelajaran dengan baik. Aktivitas guru (peneliti) dalam melaksanakan pembelajaran sangat mendukung aktivitas peserta didik dalam pembelajaran pada materi operasi hitung penjumlahan dan pengurangan bilangan bulat sehingga keterampilan berhitung peserta didik mencapai target yang diinginkan. Data hasil observasi pertemuan ke-1 dan pertemuan ke-2 pada siklus I selengkapnya pada lampiran 12 (halaman 62) dan lampiran 14 (halaman 64).

\section{Refleksi}

Data yang diperoleh melalui hasil observasi dan hasil belajar peserta didik dikumpulkan dan dianalisis. Berikut evaluasi dan hasil analisis dari hasil observasi dan hasil belajar:

\section{Hasil Observasi}

Observasi terhadap aktivitas guru (peneliti) dalam melaksanakan pembelajaran sudah sangat baik sesuai dengan rencana pelaksanaan pembelajaran yang telah disusun.

$\underline{\text { Hasil Belajar Peserta didik }}$

Tabel 4. Frekuensi Nilai Siklus I

\begin{tabular}{cccc}
\hline No. & Nilai & Frekuensi & Presentase \\
\hline 1 & 100 & 7 & $30,43 \%$ \\
2 & 90 & 6 & $26,08 \%$ \\
3 & 80 & 3 & $13,04 \%$ \\
4 & 70 & 2 & $8,7 \%$ \\
5 & 60 & 1 & $4,35 \%$ \\
6 & 50 & 2 & $8,7 \%$ \\
7 & 40 & 1 & $4,35 \%$ \\
8 & 20 & 1 & $4,35 \%$ \\
\hline \multicolumn{2}{c}{ Jumlah } & 23 & $100 \%$ \\
\hline
\end{tabular}

Penelitian ini dikatakan berhasil apabila $75 \%$ dari jumlah peserta didik menunjukkan peningkatan hasil belajar, yaitu memperoleh nilai lebih dari atau sama dengan, KKM yang ditetapkan yaitu 60. Maka pembelajaran matematika materi operasi hitung penjumlahan dan pengurangan pada bilangan bulat dengan menggunakan media kelereng warna yang telah dilaksanakan dalam 1 siklus sudah dikatakan berhasil pada siklus I.
Tabel 5. Tingkat Keberhasilan Peserta Didik Pada Siklus I

\begin{tabular}{|c|c|c|c|}
\hline $\begin{array}{c}\text { Tingkat } \\
\text { Keberhasilan }\end{array}$ & $\begin{array}{c}\text { Predikat } \\
\text { Keberhasilan }\end{array}$ & $\begin{array}{c}\text { Banyak } \\
\text { Peserta } \\
\text { Didik }\end{array}$ & $\begin{array}{c}\text { Persentase } \\
\text { Jumlah } \\
\text { Peserta } \\
\text { Didik }\end{array}$ \\
\hline $86 \%-100 \%$ & Sangat Tinggi & 13 & $56,53 \%$ \\
\hline $71 \%-85 \%$ & Tinggi & 3 & $13,04 \%$ \\
\hline $56 \%-70 \%$ & Sedang & 3 & $13,04 \%$ \\
\hline $41 \%-55 \%$ & Rendah & 2 & $8,69 \%$ \\
\hline$\leq 40$ & Sangat Rendah & 2 & $8,69 \%$ \\
\hline \multicolumn{2}{|c|}{ Jumlah } & 23 & $100 \%$ \\
\hline
\end{tabular}

Berdasarkan pada tabel di atas maka dapat diketahui bahwa nilai evaluasi pada siklus I peserta didik dari 23 peserta didik pada mata pelajaran matematika, persentase ketuntasan belajar siswa adalah 19 peserta didik $(82,60 \%)$. Sedangkan peserta didik yang belum tuntas ada 4 peserta didik $(17,40 \%)$. Hal ini menunjukkan bahwa kriteria ketuntasan minimal peserta didik sudah tergolong tinggi.

\section{Pembahasan}

Sebagaimana telah dipaparkan dalam pembahasan hasil siklus I di atas diketahui bahwa dalam penelitian ini meningkatkan keterampilan berhitung penjumlahan dan pengurangan pada bilangan bulat ditunjukkan dengan meningkatnya rata-rata nilai hasil belajar peserta didik pada setiap siklus. Hal ini juga diikuti dengan meningkatnya aktivitas pembelajaran yang dilaksanakan oleh peserta didik maupun guru.

Peningkatan hasil belajar peserta didik telah terlihat pada siklus I. Tindakan yang dilaksanakan yaitu dengan menggunakan media kelereng warna dalam pembelajaran matematika. Dengan penggunaan media kelereng warna peserta didik terlibat langsung dalam proses belajar mengajar, peserta didik dapat memanipulasi media sehingga peserta didik berperan aktif dalam pembelajaran untuk memahami konsep matematika dan mengembangkan keterampilan intelektualnya. Hal ini sesuai dengan teori Bruner bahwa dalam proses belajar anak diberi kesempatan untuk memanipulasi benda atau alat peraga dan mengotak-atik alat peraga sehingga peserta didik akan memahami suatu konsep matematika. Oleh karena itu, guru hendaknya memanfaatkan media dalam proses belajar mengajar sehingga merangsang peserta didik untuk belajar dan mengoptimalkan intelektual peserta didik.

Keterampilan berhitung peserta didik pada siklus I meningkat secara signifikan terbukti dari 
meningkatnya nilai rata-rata peserta didik yang telah sesuai dengan indikator yang diinginkan. Hal ini menunjukkan bahwa peserta didik dengan kemampuan rendah bisa meningkatkan keterampilan intelektualnya apabila dihadapkan pada strategi pembelajaran yang tepat yaitu dengan penggunaan media kelereng warna. Keterampilan berhitung merupakan salah satu kemampuan yang penting dalam kehidupan sehari-hari. Hampir semua aktivitas kehidupan manusia memerlukan kemampuan ini. Dalam pembelajaran matematika kemampuan menghitung merupakan bagian penting dalam strategi pemecahan masalah, karena soal-soal pemecahan matematika pada umumnya didominasi oleh soal-soal hitungan matematika. Hal ini berarti kemampuan menghitung penjumlahan dan pengurangan pada bilangan bulat merupakan bagian penting yang harus dikuasai oleh peserta didik sejak dini dalam pembelajaran matematika.

\section{KESIMPULAN DAN SARAN}

\section{Kesimpulan}

Penggunaan media kelereng warna dalam operasi hitung bilangan bulat dapat meningkatkan keterampilan berhitung peserta didik kelas II B SD Negeri 2 Katobengke.

\section{DAFTAR PUSTAKA}

[1] Agip, dkk. (2009). Penelitian Tindakan Kelas Untuk Guru. Bandung: Yrama.

[2] Anitah, S. (2009). Media Pembelajaran. Surakarta: UNS Press.

[3] Anonim. (2010a). Bilangan Bulat. Diakses dalam http://www.belajarmatematika.com/matematika-smp/BAB-1BILANGAN-BULAT.pdf. pada tanggal 1 Januari 2018.

[4] Arikunto, dkk. (2006). Penelitian Tindakan Kelas. Jakarta: PT Bumi Aksara.

[5] ............... (2010). Prosedur Penelitian Suatu Pendekatan Praktik. Jakarta: Rineka Cipta.

[6] Betty, B. (2010). Peningkatan Kemampuan Menghitung Penjumlahan dan Pengurangan Bilangan Bulat Melalui Media Manik-Manik Pada Siswa Kelas IV SD Negeri Balangan Teras Boyolali. Skripsi, tidak dipublikasikan. Surakarta: Universitas Sebelas Maret.

[7] Daryanto. (2011). Penelitian Tindakan Kelas dan Penelitian Tindakan Sekolah.Yogyakarta: Gava Media.

[8] Gatot, dkk. (2011). Pembelajaran Matematika SD. Jakarta: Universitas Terbuka.

[9] Heruman. (2012). Model Pembelajaran Matematika di Sekolah Dasar. Bandung: PT Remaja Rosdakarya.

[10] Hidayati dkk. (2008). Pengembangan Pendidikan IPS SD. Direktorat Jenderal Pendidikan Tinggi Departemen Pendidikan Nasional.

[11] Hoetomo. (2005). Kamus lengkap Bahasa Indonesia. Surabaya: Mitra Pelajar.

[12] Ismadi, J. (2008). Ensiklopedia Matematika. Jakarta: Nobel Edumedia.

[13] Mulyasa, E. (2009). Praktik Penelitian Tindakan Kelas. Bandung: PT Remaja Rosdakarya.

[14] Purwanto, N. (2010). Psikologi Pendidikan. Bandung: PT Remaja Rosdakarya.

[15] Sri, S. (2014). Upaya Meningkatkan Prestasi Belajar Matematika Melalui Penggunaan Alat Peraga Kartu Warna Pada Materi Operasi Hitung Bilangan Bulat Di Kelas IV MI Muhammadiyah Munggur. Skripsi, tidak dipublikasikan. Yogyakarta: Universitas Islam Negeri Sunan Kalijaga.

[16] Sugiyono. (2012). Metode Penelitian Pendidikan (Pendekatan Kuantitatif, Kualitatif, dan $R \& D)$. Bandung: Alfabeta.

[17] Sundayana, R. (2014). Media dan Alat Peraga dalam Pembelajaran Matematika. Bandung: Alfabeta.

[18] Syah, M. (2008). Psikologi Pendidikan dengan Pendekatan Baru. Bandung: Remaja Rosda Karya.

[19] Umar, H. (2004). Metode Riset Ilmu Administrasi. Jakarta: Gramedia Pustaka Utama. 